\title{
Preliminary insights into magneto-biomonitoring (Tilia europaea and Acer pseudoplatanus) as an alternative roadside particulate air pollution technology
}

\author{
A. L. Power ${ }^{1,2}$, A. T. Worsley ${ }^{1}$, C. A. Booth ${ }^{2}$ \& K. M. Farr ${ }^{2}$ \\ ${ }^{1}$ Edge Hill University College, Ormskirk, Lancashire, UK \\ ${ }^{2}$ Research Institute in Advanced Technologies (RIATec), \\ The University of Wolverhampton, West Midlands, UK
}

\begin{abstract}
Urban roadside particulate air pollution, deposited on tree leaf surfaces (Lime: Tilia europaea; Sycamore: Acer pseudoplatanus), has been monitored (July 2003 to November 2003) by mineral magnetic technologies. The nature of this work is particularly important because particulate pollution affects human health (i.e. cardio-vascular and respiratory systems). Leaves were collected from four roadside locations and a woodland park within the City of Wolverhampton, West Midlands, U.K. Data analyses reveal that significant $(\mathrm{p}<0.001)$ site-specific differences are chiefly attributed to differences in types of traffic management and associated vehicular behaviour, but may also be influenced by the type of vehicular engine (notably diesel) and localised conditions. Moreover, evidence suggests magnetic concentration parameters are a surrogate for particulate air pollution. Given the speed, measurement sensitivity and non-destructive nature of the technique, it is proposed this low-cost approach offers some advantages over other technologies currently used to monitor urban roadside particulate pollution.
\end{abstract}

Keywords: environmental magnetism, tree leaves, $P M_{10}$, vehicular pollution monitoring, traffic management. 


\section{Introduction}

Atmospheric particles exist in various forms (sub-micro aerosols to visible dusts). Particulate pollution can have serious and damaging influences on human health, affecting cardio-vascular and respiratory systems. Typically, the finest particle sizes (diameter $<10 \mu \mathrm{m}$; known as $\mathrm{PM}_{10}$ ) exacerbate these illnesses. This is because they are not filtered-out by the nasal tract and, as a consequence, are able to penetrate deep into human lungs, which can reduce pulmonary function and promote alveolar inflammation [1, 2]. For instance, coal-derived particulate pollution was a notable component of the London smogs (1950s), which were responsible for high mortality rates and also contributed to acute illness in many people. This culminated in the first Clean Air Act (1956). In the UK, nowadays combustion from petrol $(\sim 5 \%)$ and diesel $(\sim 19 \%)$ powered vehicles is the main producer of $\mathrm{PM}_{10}$ pollution [3]

Many studies have explored relationships between the magnetic and physicochemical properties of dusts and sediments, which has allowed mineral magnetic measurements to be identified as a suitable proxy for geochemical, radioactivity, organic matter content and particle size data [4-13]. Hence, magnetic techniques have aided pollution studies [14-20] and, more recently, promoted magnetobiomonitoring of urban leaves to be recognised as a possible alternative or supporting technology for particulate pollution studies [21-24].

This pilot study presents an insight into the (i) use of urban tree leaves as dust depositories; (ii) application of mineral magnetic measurements as a $\mathrm{PM}_{10}$ proxy; (iii) associations between particulate pollution and traffic management/vehicle behaviour; and (iv) promotion of mineral magnetic technologies as an alternative roadside particulate air pollution monitoring tool.

\section{Magneto-biomonitoring technology}

Mineral magnetic analyses are now considered a routine form of analysis when investigating the compositional properties of soils, sediments and dusts [25]. Compared with other analytical methods, mineral magnetics provides a compositional tool, which is reliable, rapid, non-destructive, inexpensive and sensitive to low detection levels [26]. Consequently, this has assisted understanding linkages between health and respirable airborne particulate matter [27], association with organic matter [9, 10], progressed spatial and temporal pollution studies [14-20], benefited air-borne particulate discrimination [17, 2830] and has recently promoted its suitability for aiding biomonitoring of air quality $[22,23,31,32]$.

Urban trees leaf surfaces are known to intercept and retain airborne particulates [33-37] allowing traffic emissions to be monitored [38] and linkages made with $\mathrm{PM}_{10}$ pollution [39]. Magnetic techniques have been used to demonstrate decreases in pollution concentrations on leaf surfaces (and in soils) with distance from roads [17, 22, 23, 40] and have highlighted their use as a proxy for vehicular heavy metal pollution [24]. Furthermore, the ability of differing tree species to retain particulates has also been recognised [23]. 


\section{A preliminary study: Wolverhampton city, U.K.}

\subsection{Site descriptions}

Leaf samples were collected from four roadside sites (Figure 1) and a woodland park within the Wolverhampton conurbation, West Midlands, UK. In all cases, sample trees are $<15 \mathrm{~m}$ from traffic.

(a)

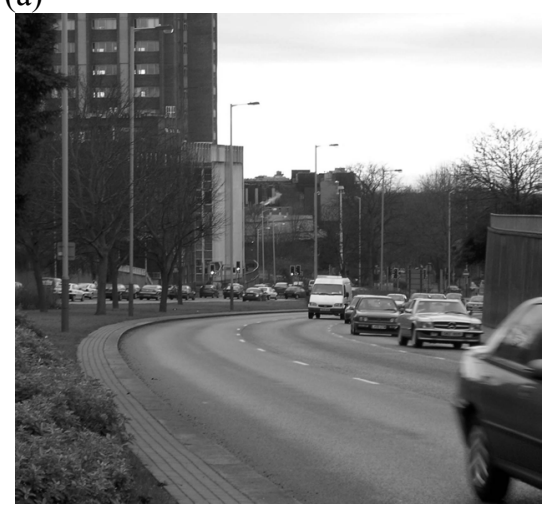

(c)

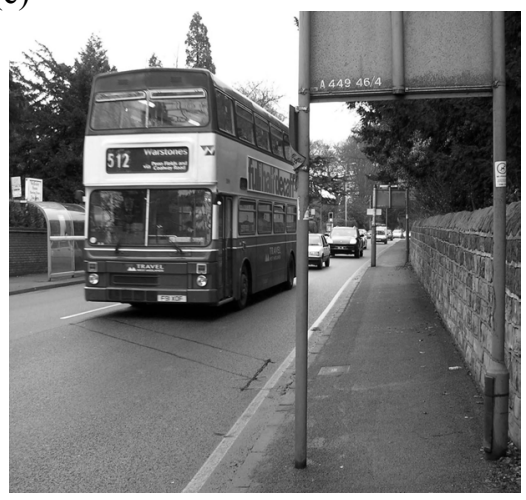

(b)

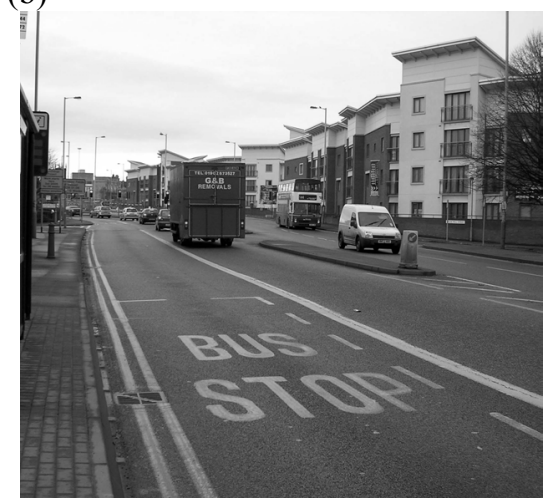

(d)

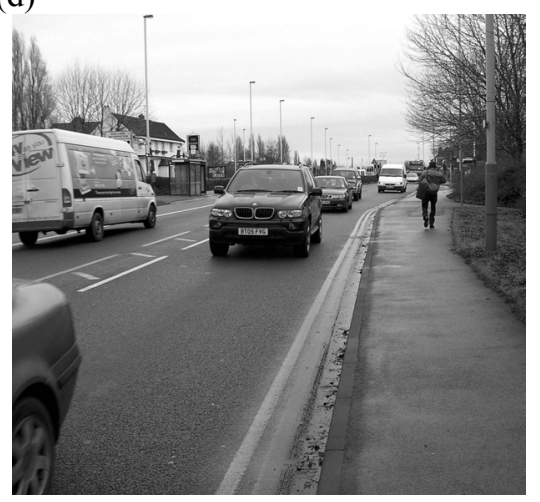

Figure 1: Urban roads of Wolverhampton (a) St Peters Ring Road, (b) Union Mill Street, (c) Penn Road and (d) Willenhall Road.

(1) St Peters Ring Road (National Grid Reference (NGR): SO 914 990; Plate 1a) comprises a western section $(500 \mathrm{~m})$ of the ring road that surrounds Wolverhampton city centre with two sets of traffic lights at either end. The sample trees are positioned midway in a central vegetated reservation $(15 \mathrm{~m}$ wide). The road is slightly inclined with three lanes of vehicles travelling uphill and two lanes downhill, exposing the trees to 5 lanes of traffic pollution, mainly cars and heavy duty vehicles with occasional traffic standstills; (2) Union Mill 
Street (NGR: SO 921 986; Plate 1b) is located on the eastern outskirts of the city centre. High traffic loads are experienced along this main approach to the city with lorries, buses and cars frequently idling at a set of traffic lights; (3) Penn Road (NGR: SO 903 968; Plate 1c) is a busy and frequently used south-westerly route to/from the city centre, set in residential surroundings with two lanes of traffic, heavily used by buses. Traffic standstills are frequent due to the presence of a bus stop and traffic signals at either end of the 150m section; (4) Willenhall Road (NGR: SO 984 938; Plate 1d) is situated in a residential area east of the city centre. Traffic intensities are high along this road, but regular standstills are infrequent; and (5) Mosley Park (NGR: SO 950 970) is a small woodland park, located in a sub-urban residential area of Willenhall. All adjacent roads are mainly residential and, as such, experience low traffic intensities.

\subsection{Materials and methods}

Leaves were collected from two tree species (Lime: Tilia europaea; Sycamore: Acer pseudoplatanus) at each site, at approximately fortnightly intervals $(22 / 07 / 2003-12 / 10 / 2003)$. On each occasion, collection days were always after a minimum of 3-days of dry weather. Samples were collected at the same heights from each tree $(1.8-2.0 \mathrm{~m})$ to avoid ground contamination (splash) and minimise pedestrian disturbance.

Five leaves from each tree were compressed into $10 \mathrm{cc}$ plastic pots and their dry weights recorded to obtain mass specific values. All samples were then subjected to the same analysis procedures [25], to determine Low-frequency Magnetic Susceptibility $\left(\chi_{\mathrm{LF}}\right)$; Anhysteretic Remanence Magnetisation (ARM); and Saturated Isothermal Remanent Magnetisation (SIRM). Interpretations of these parameters are widely available [41].

Particulate matter was monitored with a P. Track Ultrafine Particulate Counter (Model 8525), with the probe positioned immediately adjacent to those same trees used for leaf sampling.

\subsection{Results}

Preliminary statistical analyses validate the use of mineral magnetic measurements. Correlation coefficients indicate significant $(\mathrm{p}<0.01)$ kinships exist between $\mathrm{PM}_{10}$ and mineral magnetic measurements (Table 1). For Lime tree leaves, the association is not always applicable. In contrast, for Sycamore tree leaves, the relationship is significant for all magnetic parameters. Despite the small data population, based on this evidence, magnetic measurements are deemed a suitable proxy for $\mathrm{PM}_{10}$ pollution. However, a cautionary note is expressed about the reliability of the data derived from Lime tree leaves.

Mineral magnetic data is presented for both Lime (Table 2) and Sycamore (Table 3) leaves. For both species, Union Mill Street has the highest magnetic concentration values and Willenhall Road has the lowest magnetic concentration values for all four roads. Since the physical and biological properties of the leaves are different, it is inappropriate to compare inter-species data. However, 
despite these differences, similar data trends for both species support the validity of this methodological approach.

Table 1: $\quad$ Relationships between $\mathrm{PM}_{10}$ and magnetic measurements $(\mathrm{n}=5)$.

\begin{tabular}{|l|c|c|l|c|c|}
\hline \multicolumn{3}{|c|}{ Lime: Tilia europaea } & \multicolumn{2}{c|}{ Sycamore: Acer pseudoplatanus } \\
\hline $\begin{array}{l}\text { Magnetic } \\
\text { Parameter }\end{array}$ & $\mathrm{R}^{2}$ & $\mathrm{p}$-value & $\begin{array}{l}\text { Magnetic } \\
\text { Parameter }\end{array}$ & $\mathrm{R}^{2}$ & $\mathrm{p}$-value \\
\hline$\chi_{\mathrm{LF}}$ & 0.597 & $>0.05$ & $\chi_{\mathrm{LF}}$ & 0.793 & $<0.05$ \\
\hline ARM & 0.747 & $>0.05$ & ARM & 0.940 & $<0.01$ \\
\hline SIRM & 0.775 & $<0.05$ & SIRM & 0.958 & $<0.01$ \\
\hline
\end{tabular}

Table 2: $\quad$ Summary mineral magnetic data (mean and standard deviation) for urban roadside dusts on Lime tree leaves.

\begin{tabular}{|l|c|c|c|}
\hline Site & $\begin{array}{c}\chi_{\mathrm{LF}} \\
\left(10^{-7} \mathrm{~m}^{3} \mathrm{~kg}^{-1}\right)\end{array}$ & $\begin{array}{c}\text { ARM } \\
\left(10^{-5} \mathrm{Am}^{2} \mathrm{~kg}^{-1}\right)\end{array}$ & $\begin{array}{c}\text { SIRM } \\
\left(10^{-5} \mathrm{Am}^{2} \mathrm{~kg}^{-1}\right)\end{array}$ \\
\hline Willenhall Road $(\mathrm{n}=6)$ & $0.16(0.13)$ & $0.43(0.11)$ & $28.80(6.56)$ \\
\hline Penn Road $(\mathrm{n}=6)$ & $1.92(0.42)$ & $1.63(0.31)$ & $145.59(14.77)$ \\
\hline St. Peters $(\mathrm{n}=6)$ & $1.98(0.98)$ & $1.52(0.78)$ & $157.55(56.20)$ \\
\hline Union Mill Street $(\mathrm{n}=6)$ & $2.22(0.98)$ & $2.00(1.38)$ & $233.09(61.42)$ \\
\hline All Roads $(\mathrm{n}=24)$ & $1.57(1.07)$ & $1.40(0.96)$ & $141.26(84.48)$ \\
\hline Mosley Park $(\mathrm{n}=5)$ & $0.40(0.12)$ & $0.41(0.08)$ & $52.24(16.96)$ \\
\hline
\end{tabular}

Table 3: $\quad$ Summary mineral magnetic data (mean and standard deviation) for urban roadside dusts on Sycamore tree leaves.

\begin{tabular}{|l|c|c|c|}
\hline Site & $\begin{array}{c}\chi_{\mathrm{LF}} \\
\left(10^{-7} \mathrm{~m}^{3} \mathrm{~kg}^{-1}\right)\end{array}$ & $\begin{array}{c}\text { ARM } \\
\left(10^{-5} \mathrm{Am}^{2} \mathrm{~kg}^{-1}\right)\end{array}$ & $\begin{array}{c}\text { SIRM } \\
\left(10^{-5} \mathrm{Am}^{2} \mathrm{~kg}^{-1}\right)\end{array}$ \\
\hline Willenhall Road $(\mathrm{n}=6)$ & $0.44(0.23)$ & $0.54(0.29)$ & $56.98(21.98)$ \\
\hline Penn Road $(\mathrm{n}=6)$ & $1.88(0.58)$ & $1.61(0.59)$ & $134.89(36.00)$ \\
\hline St. Peters $(\mathrm{n}=6)$ & $0.68(0.29)$ & $0.66(0.15)$ & $55.34(10.76)$ \\
\hline Union Mill Street $(\mathrm{n}=6)$ & $1.70(0.67)$ & $1.89(1.11)$ & $179.19(72.67)$ \\
\hline All Roads $(\mathrm{n}=24)$ & $1.17(0.78)$ & $1.18(0.85)$ & $106.60(66.86)$ \\
\hline Mosley Park $(\mathrm{n}=5)$ & $0.35(0.06)$ & $0.48(0.12)$ & $55.65(9.04)$ \\
\hline
\end{tabular}

Magnetic concentration data for Penn Road is similar to St Peters Ring Road for Lime trees, but it is notably higher for Sycamore trees. This suggests localised conditions (e.g. environmental, meteorological or anthropogenic) of these sites, maybe influencing or disturbing particulate deposition.

Mosley Park was included in this study to provide a comparative background control, indicative of an urban site with low traffic intensities. For both species, it is to be expected that this site has lower magnetic concentration values than any of the roads. However, despite the notable differences between sites, Mosley 
Park and the Willenhall Road locations display similar magnetic concentration values. Since the control site is not near to any major traffic routes, this suggests either the Mosley Park leaves receive particulate pollution from an unknown source or the traffic intensity and/or traffic flow conditions at the Willenhall Road site are causing only minor particulate pollution to be deposited.

Traffic studies indicate Willenhall Road has the highest traffic flow (mean of 1342 vehicles one-way) of all four roads, during morning peak travel times (07.45 - 08.45). In contrast, Union Mill Street has the lowest traffic flow (mean of 935 vehicles one-way) during morning peak travel times. This is in marked contrast to the trend of the magnetic concentration values. This suggests either magnetic concentration measurements are not a suitable proxy for particulate pollution at these sites (not consistent with Table 1) or the data variations are attributable to inter-site differences (e.g. traffic flow conditions and/or immediate environmental surroundings).

\subsection{Discussion}

Magnetic measurements highlight significant (ANOVA: $p<0.001$ ) inter-site differences between particulate pollution quantities deposited on the leaves of two tree species. Results indicate these differences are not associated with traffic quantities passing each site but are attributable to the type of traffic management controlling each site. For instance, despite high traffic flow volumes, Willenhall Road had the lowest particulate pollution (i.e. low magnetic values) because the traffic was free-flowing and was infrequently stationary. Therefore, the vehicles were releasing lower particulate pollution because they were not stopped with engines idling or changing gears. In contrast, despite low traffic flow volumes, Union Mill Street had the highest particulate pollution (i.e. high magnetic values) because traffic was frequently stationary at traffic lights. Therefore, vehicles were expelling greater particulate concentrations because the engines were idling and/or changing gears at this site.

Traffic conditions on the Penn Road are notably different to those on $\mathrm{St}$ Peters Ring Road. During peak travel times, Penn Road traffic frequently queues at several sets of traffic lights for short intervals and, unlike the other roads, traffic flow is restricted to a single lane. In contrast, St Peters Ring Road is free flowing and multi-laned. The Sycamore tree data clearly reflect these traffic conditions, with Penn Road experiencing greater particulate pollution because vehicles are frequently stopped with engines idling or changing gears to moveaway. In contrast, St Peters Ring Road has lower particulate pollution because traffic only occasionally stops. Traffic is usually free moving, with less particulate matter released.

It is also important to note, of all roads, Union Mill Street had the highest proportion of lorries. Likewise, Penn Road had the highest proportion of buses. Since these both vehicles types are normally diesel powered and, therefore, expel greater particulate quantities, it is probable that they contribute to the high particulate pollution at these sites. 


\subsection{Future work}

The findings from this pilot study highlight the need for further study, which should include: (1) the nature of the relationship between magnetic and particulate properties explored fully in specific urban environments and individual sites, to test the reliability of magnetic technologies as a proxy for both $\mathrm{PM}_{10}$ and $\mathrm{PM}_{2.5}$ pollution; (2) a sampling regime that incorporates more sample collection sites, which for comparative purposes should also include several sites with similar traffic management (e.g. at traffic lights, dual and single lane carriageways or free flowing traffic conditions for each site) and, where possible, similar localised settings; (3) examination of leaves from other tree species as receptors for particulate pollution; (4) employment of spatial magnetic data to create local/regional pollution maps; (5) discriminate magnetocharacterization of particulates from petrol and diesels powered engines; (6) street dust comparisons between pavement and leaf-covered particulates; and finally, (7) further investigation of the most appropriate sample preparation procedure (and associated units) when conducting this type of bio-monitoring exercise. The approach used here (mass specific measurements) restricts data comparison with similar publications. However, other approaches, which have used leaf-ratio indexes or leaf surface areas (pixel scanning of leaves), are comparatively complex and time-consuming. Therefore, a new sample preparation procedure needs validating (e.g. washing or wiping leaves), which permits the traditional, mass specific measurements, approach to be used.

\section{Conclusions}

This study uses mineral magnetic parameters as surrogates for vehicular-derived particulate pollution. Data originated from four urban roadside locations and one urban woodland park and demonstrates site-specific differences. These are chiefly attributed to differences in vehicle behaviour (e.g. free flowing, stationary and idling or moving-away and changing gears) at various traffic management situations (e.g. at traffic lights, dual and single lane carriageways or free flowing traffic conditions for each site), but may also be influenced by the type of vehicular powered engine (i.e. petrol or diesel) and localised conditions (e.g. environmental, meteorological or anthropogenic).

Initial evidence suggests magnetic concentration parameters are a suitable proxy for particulate air pollution. Given the speed, measurement sensitivity and non-destructive nature of the technique, it is proposed that this low-cost approach may offer some advantages over other technologies currently used to monitor urban roadside particulate pollution.

\section{Acknowledgements}

All authors gratefully acknowledge and thank the technical staff of the School of Applied Sciences at The University of Wolverhampton. ALP also thanks Edge Hill for providing the financial support to publish this work. 


\section{References}

[1] Brunekfreff, B. \& Holgate, S. T., Air pollution and health. The Lancet, 360, pp. 1233-1242, 2002.

[2] Zanobetti, A., Schwartz, J., Samoli, E., Gryparis, A., Touloumi, G., Peacock, J., Anderson, R.H., Le Tertre, A., Bobros, J., Celko, M., Goren, A., Forsberg, B., Michelozzi, P., Rabczenko, D., Hoyos, S.P., Wichmann H.E. \& Katsouyanni, K., The temporal pattern of respiratory and heart disease mortality in response to air pollution. Environmental Health Perspectives, 111, pp. 1188-1193, 2003

[3] Department of the Environment, Transport and the Regions (DEFRA) Particulates: Sources of Airborne Particulate Matter. <http://www.defra.gov.uk/environment/airquality/aqs/particle/5.htm $>$ published 29/10/1998, accessed 2/2/06.

[4] Bonnett, P.J.P., Appleby, P.G. \& Oldfield, F., Radionuclides in coastal and estuarine sediments from Wirral and Lancashire. Science of the Total Env., 70, pp. 215-236, 1988.

[5] Oldfield, F., Richardson, N. \& Appelby, P.G., ${ }^{241}$ Am and ${ }^{137}$ Cs activity in fine-grained saltmarsh sediments from parts of the $N$ E Irish Sea shoreline. Journal of Environmental Radioactivity, 19, pp. 1-24, 1993.

[6] Hutchinson, S.M. \& Prandle, D., Siltation in the salt marsh of the Dee Estuary derived from ${ }^{137} \mathrm{Cs}$ analysis of shallow cores. Estuarine, Coastal and Shelf Science, 38, pp. 471-478, 1994.

[7] Clifton, J., McDonald, P., Plater, A. \& Oldfield, F., Relationships between radionuclide content and textural properties in Irish Sea intertidal sediments. Water, Air \& Soil Pollution, 99, pp. 209-216, 1997.

[8] Clifton, J., McDonald, P., Plater, A. \& Oldfield, F., Derivation of a grainsize proxy to aid the modelling and prediction of radionuclide activity in salt marshes and mud flats of the Eastern Irish Sea. Estuarine, Coastal \& Shelf Science, 48, pp. 511-518, 1999.

[9] Xie, S., Dearing, J.A., Bloemandal, J. \& Boyle, J.F., Association between the organic matter content and magnetic properties in street dust, Liverpool, U.K. Science of the Total Env., 241, pp. 205-214, 1999.

[10] Xie, S., Dearing, J.A. \& Bloemandal, J., The organic matter content of street dust in Liverpool, UK and its association with dust magnetic properties. Atmospheric Env., 34, pp. 269-275, 2000.

[11] Zhang, W., Yu, L. \& Hutchinson, S.M., Diagenesis of magnetic minerals in the intertidal sediments of the Yangtze Estuary, China, and its environmental significance. Science of the Total Env., 266, pp. 169-175, 2001.

[12] Booth, C.A., Walden, J., Neal, A. \& Smith, J.P., Use of mineral magnetic concentration data as a particle size proxy: a case study using marine, estuarine and fluvial sediments in the Carmarthen Bay area, South Wales, U.K. Science of the Total Env., 347, pp. 241-253, 2005.

[13] Shilton, V.F., Booth, C.A., Giess, P., Mitchell, D.J. \& Williams, C.D., Magnetic properties of urban street dust and its relationship to organic 
matter content in the West Midlands, U.K. Atmospheric Env., 39, pp. 3651-3659, 2005.

[14] Hunt, A., Jones, J. \& Oldfield, F., Magnetic measurements and heavy metals in atmospheric particulates of anthropogenic origin. Science of the Total Env., 33, pp. 129-139, 1984.

[15] Beckwith, P.R., Ellis, J.B., Revitt, D.M. \& Oldfield, F., Heavy metal and magnetic relationships for urban source sediments. Physics of the Earth Planetary Interiors, 42, pp. 67-75, 1986.

[16] Flanders, P.J., Collection, measurement and analysis of airborne magnetic particulates from pollution in the environment. Journal of Applied Physics, 75, pp. 5931-5936, 1994.

[17] Hoffman, V., Knab, M. \& Appel, E., Magnetic susceptibility mapping of roadside pollution. Journal of Geochemical Exploration, 66, pp. 313-326, 1999.

[18] Muxworthy, A.R., Effect of grain interactions on the frequency dependence of magnetic susceptibility. Geophysical Journal International, 144, pp. 441-447, 2001.

[19] Muxworthy, A.R., Schmidbauer, E. \& Petersen, N., Magnetic properties and Mössbauer spectra of urban atmospheric particulate matter: a case study from Munich, Germany. Geophysical Journal International, 150, pp. 558-570, 2002.

[20] Muxworthy, A.R., Matzka, J., Davila, A.F. \& Petersen, N., Magnetic signature of daily sampled atmospheric particulates. Atmospheric Env., 37, pp. 4163-4169, 2003

[21] Knab, M., Appel, E. \& Hoffmann, V., The anthropogenic dust load of coniferous tree needles in the Black Forest area, SW Germany: an approach using magnetic susceptibility (MS). In: Abstracts, XXIII General Assembly of the International Union of Geodesy and Geophysics, Sapporo, GAI.02/01A/A16-007. A.261. 2003.

[22] Matzka, J. \& Maher, B.A., Magnetic biomonitoring of roadside tree leaves: identification of spatial and temporal variations in vehicle-derived particulates. Atmospheric Env., 33, pp. 4565-4569, 1999.

[23] Moreno, E., Sagnotti, L., Dinarès-Turell, J., Winkler, A. \& Cascella, A., Biomonitoring of traffic air pollution in Rome using magnetic properties of tree leaves. Atmospheric Env., 37, pp. 2967-2977, 2003.

[24] Gautam, P., Blaha, U. \& Appel, E., Magnetic susceptibility of dust-loaded leaves as a proxy of traffic related heavy metal pollution in Kathmandu city, Nepal. Atmospheric Env., 39, pp. 2201-2211, 2005.

[25] Walden, J., Smith, J.P. \& Oldfield F., (Eds.) Environmental Magnetism, A Practical Guide. Q.R.A., Technical Series No. 6., pp. 243, 1999.

[26] Walden, J., Smith, J.P. \& Dackombe, R.V., A comparison of mineral magnetic, geochemical and mineralogical techniques for compositional studies of glacial diamictons. Boreas 25, pp. 115-130, 1996.

[27] Morris, W.A., Versteeg, J.K., Bryant, D.W., Legzdins, A.E., McCarry, B.E. \& Marvin, C.H., Preliminary comparisons between mutagenicity and 
magnetic susceptibility of respirable airborne particulate. Atmospheric Env., 29, pp. 3441-3450, 1995.

[28] Hunt, A., The application of magnetic methods to atmospheric aerosol discrimination, Physics Earth \& Planet. Interiors, 42, pp. 10-21, 1986.

[29] Hunt, A., 1988, 'Atmospheric magnetic particles', Unpublished Ph.D. thesis. University of Liverpool.

[30] Shu, J., Dearing, J., Morse, A., Yu, L. \& Li, C., Magnetic properties of daily sampled total suspended particulates in Shanghai. Environmental Science \& Technology, 34, pp. 2393-2400, 2000.

[31] Hanesch, M., Scholger, R. \& Rey, D., Mapping dust distribution around an industrial site by measuring magnetic parameters of tree leaves. Atmospheric Env., 37,pp. 5125-5133, 2003.

[32] Urbat, M., Lehndorf, E. \& Schwark, L., Biomonitoring of air quality in the Cologne conurbation using pine needles as a passive sampler. Atmospheric Env., 38, pp. 3781-3792, 2004.

[33] Schädlich, G., Weißflog, L. \& Schüürmann, G., Magnetic susceptibility in conifer needles as indicators of fly ash deposition. Fresenius Environmental Bulletin, 4, pp. 7-12, 1995.

[34] Beckett, K.P., Freer-Smith, P.H. \& Taylor, G., Urban woodlands: their role in reducing the effects of particulate pollution. Environmental Pollution, 99, pp. 347-360, 1998.

[35] Nowak, D.J., McHale, P.J., Ibarra, M., Crane, D., Stevens, J.C. \& Luley, C.J., Modelling the effects of urban air vegetation on air pollution. Air Pollution Model \& Its Application, 12, pp. 399-407, 1998.

[36] Alfani, A., Baldantoni, D., Maisto, G., Bartoli, G. \& De Santo, V., Temporal and spatial variation in $\mathrm{C}, \mathrm{N}, \mathrm{S}$ and trace element contents in the leaves of Quercus ilex within the urban area of Naples. Environmental Pollution, 109, pp. 119-129, 2000.

[37] Lau, O.W. \& Luk, S.F., Leaves of Bauhinia blakeana as indictors of atmospheric pollution in Hong Kong. Atmospheric Env., 35, pp. 31133120, 2001.

[38] Jouraeva, V.A., Johnson, D.L., Hassett, J.P. \& Nowak, D.J., Differences in accumulation of PAHs and metals on the leaves of Tilla $\mathrm{x}$ euchlora and Pyrus calleryana. Environmental Pollution,120, pp. 331-338, 2002.

[39] Freer-Smith, P.H., Holloway, S. \& Goodman, A., The uptake of particulates by an urban woodland: site description and particulate composition. Environmental Pollution, 95, pp. 27-35, 1997.

[40] Bityukova, L., Scholger, R. \& Birke, M., Magnetic susceptibility as an indicator of environmental pollution of soils in Tallinn. Physics \& Chemistry of the Earth, 24, pp. 829-835, 1999.

[41] Booth, C.A., Fullen, M.A., Smith, J.P., Hallett, M.D., Walden, J., Harris, J. \& Holland, K., Factor analysis of particle size specific mineral magnetic measurements on agricultural topsoils from the Isle of Man. Comm. in Soil Science \& Plant Analysis, 37, pp. 249-273, 2006. 